\title{
USEFULL OF LOCAL DRINKS (ARAK BALI) MATERIALS AS MIXED DRINKS IN TOURISM INDUSTRY IN BALI
}

\author{
Setyowati Ayu Widuri. \\ Sekolah Tinggi Pariwisata Nusa Dua Bali \\ widuriayu@gmail.com
}

\begin{abstract}
Bali is one of the areas that have great potential in the field of tourism. Bali island became well known internationally for its natural beauty, artistry, diversity of culture and social traditions inspired by Hinduism. Availability of facilities and infrastructure such as hotels, restaurants, travel agencies and other travel, tourist visits to Bali is increasing. Along with the development of the tourism industry and increased competition among tourist destination, local cultures becomes valuable as products and activities to attract tourists. Gastronomic food and drink is one of the local culture has an important role for the food and beverages can also be a center of tourist experience. Gastronomic tours arises from the desire of the tourists themselves who want to gain experience not only from the natural beauty, but also of traditional food products and beverages served.

Drinks local / traditional are all kinds of drinks are made and processed using local materials and processing methods are many and varied, and has a typical local area and commonly consumed by the local community. Drinks as one aspect of the culture of a nation, can characterize the nation's identity. Along with the development of gastronomic tours in Bali and look at potential tourists, especially foreign tourists who have the habit of drinking alcoholic beverage, so today many restaurants and hotels in Bali serves mixed drinks made from local beverages (especially Arak Bali).

The aim of this research is to find related the utilization of local drinks (Arak Bali) as an ingredient mixed drinks in the tourism industry. This research was conducted in order to better bring some uniqueness of Bali, especially in the field of drinks, so the local genius of Bali have an active role in the era of globalization which will come as well as to improve the economic conditions of local communities.
\end{abstract}

Keywords : traditional beverage, arak bali, mixed drinks

\section{Research Background}

Bali is one of the areas that have great potential in the field of tourism. Bali island became well known internationally for its natural beauty, artistry, diversity of culture and social traditions inspired by Hinduism. Availability of facilities and infrastructure such as hotels, restaurants, travel agencies and other 
travel, tourist visits to Bali is increasing. Along with the development of the tourism industry and increased competition among tourist destination, local cultures becomes valuable as products and activities to attract tourists.

Gastronomic food and drink is one of the local culture has an important role for the food and beverages can also be a center of tourist experience. Gastronomic tours arises from the desire of the tourists themselves who want to gain experience not only from the natural beauty, but also of traditional food products and beverages served. Some tourist destinations using gastronomy as a tourist puller and many use to promote gastronomic tourism. Results of research Richie and Zine in the Americas, namely: (1) craft, (2) tradition, (3) the history of a place / area, (4) architecture, (5) food and beverage local / traditional, (6) art and music, (7) the way of life of a society, (8) religion, (9) language, and (10) local clothing / traditional. From these results it can be seen that one of the attractions for tourists is the food and drink local / traditional.

Drinks local / traditional are all kinds of drinks are made and processed using local materials and processing methods are many and varied, and has a typical local area and commonly consumed by the local community. Drinks as one aspect of the culture of a nation, can characterize the nation's identity. For example, Sake is known as one of Japan's national identity, Teh Tarik Malaysia as the nation's identity.

In Bali, Arak is one type of alcoholic beverage traditional Balinese latter is sufficiently developed in the tourism industry. Literally drink Arak Bali has developed since the entry of Hinduism in Bali and has become a genuine beverage Bali, not only for people but also religiously reserved for the gods - Goddess accordance beliefs of Hinduism. Arak Bali is one of the traditional alcoholic beverage derived from a traditional herb made from glutinous rice and coconut water is processed through a fairly simple process, namely by fermentation and distillation, these drinks contain alcohol content is high at $40 \%$. The drink is also quite often used and consumed by the local community in any religious ceremony or custom events.

Along with the development of gastronomic tours in Bali and look at potential tourists, especially foreign tourists who have the habit of drinking alcoholic beverage, so today many restaurants and hotels in Bali serves mixed drinks made from local beverages (especially Arak Bali). Based on these descriptions, the authors are interested in doing research related to the utilization of local drinks (Arak Bali) as an ingredient mixed drinks in the tourism industry. This research was conducted in order to better bring some uniqueness of Bali, especially in the field of drinks, so the local genius of Bali have an active role in the era of globalization which will come as well as to improve the economic conditions of local communities.

\section{Literature Review}

Here are some previous research related to the mixed drink based on traditional beverage, among others:

According to Imanuella, Sulistyawati and Ansori in their research that influence of usage citric acid and sodium bicarbonate. This study aims to determine the effect of the use of citric acid and sodium bicarbonate as well as a mixture of both the taste and the effect of extra sparkle in lime carbonated 
beverage, as well as knowing the community favorite against lime carbonated beverage in terms of flavor and extra sparkle effect. Variations in the use of citric acid is $0: 45 \mathrm{~g}, 0.60 \mathrm{~g}, 0.75 \mathrm{~g}, 0.90 \mathrm{~g}$; and $0.75 \mathrm{~g}$ of sodium bicarbonate and 1:50 g. Assessment of the results of the taste and the effect of extra sparkle in lime carbonated beverage made subjectively by the sensory test A test dn. Data was analyzed by factorial for sensory test and descriptive test percentages for joy. The results showed that the use of citric acid and sodium bicarbonate either mixed or unmixed affect the taste and effects of extra sparkle in lime carbonated beverages. Samples were most appreciated by the public, namely lime carbonated beverage with the use of $0.75 \mathrm{~g}$ of citric acid and $1.5 \mathrm{~g}$ of sodium bicarbonate. Similarly, lime carbonated beverage products best experimental results that lime carbonated beverage with the use of $0.75 \mathrm{~g}$ of citric acid and $1.5 \mathrm{~g}$ of sodium bicarbonate.

Research doing by Ristiana, Wijana and Ika Putri about Study of processing Plant Nipah Cocktails. The aims of this research was to determine the concentration of sugar syrup and palm fruit maturity level appropriate to produced a cocktail palm which have a good organoleptic qualities and to know the results of the chemical qualities of the best treatments which include total dissolved solids testing, total sugar, crude fiber, total carbohydrate, moisture content and levels ash. This study used a combination of two factors, the first factor level ripeness of the fruit (B), which consists of 2 levels and sugar syrup second factor (K) which consists of 4 levels. Organoleptic analysis of the data used method of hedonic scale scoring with 30 panelists. The parameters considered include flavor, aroma, color, texture and overall. Data obtained from organoleptic then performed with the Friedman test data processing. Selection of the best treatment was done by using the method of index effectiveness. Election results of chemical qualities test followed the best treatment. Organoleptic test results obtained only flavor attributes were not significantly different, whereas the attributes of aroma, color and texture of the real effect of the cocktail palm. The best treatment in the combination treatment is rather old fruit maturity and concentration of sugar syrup 20 oBrix content of total dissolved solids with the results of chemical qualities tests total dissolved solids of 20.7 oBrix, total sugar by $10.8 \%, 0.25 \%$ crude fiber, total carbohydrate by $13.98 \%$, water content of $84.56 \%$, and the ash content of $0.86 \%$. Based on the results of research studies need to be done about the shelf life of the product, packaging and texture of palm fruit can 2 be made uniform through the process of high pressure and sterilization

\section{Research Method}

In the design of the research, using qualitative methods through observation or observation, interviews and documentation. Interviews were conducted to the bar manager and a bartender by using sampling purposive sampling techniques in use in selecting a bar that sells Arak-based mixed drinks. Observations to obtain data needed such as in relation to the conduct of research such as observing the physical condition of the bar and beverages are served. Documentation is made to collect all the physical evidence in the form of photos and videos related to information and research data. The study of literature in getting the reference Badung tourism official website and other supporting materials. 
Stages of research began with the observation to determine Bar which will be used as a place / location where the latter study at Bar selected will perform an interview with the manager and bartender who was directly involved in the sale of mixed drinks and taking photographs for documentation. In each of the Bar, the writer gives the same questions to the manager and bartender on duty, namely:

1) Type Arak Bali what possible use as an ingredient in mixed drinks to tourists in Bar you?

2) Drink a mixture of any base ingredients using Arak Bali?

3) What is the composition / mixed drink recipes that use basic ingredients Arak Bali?

4) How does the interest of tourists to the base ingredients mixed drinks using Arak Bali in Bar where you work?

Observations conducted along Kuta, Seminyak and Nusa Dua where the region considered to be the center of activity in Badung Tourism. From the results of preliminary observations and then have some Bar who sell arak as one of the ingredients mixed drinks are sold to visitors who come to buy drinks. The bar include the following:

a. Tropical Ocean Restaurant and Bar was established in November 2003 in Gerbangutama BTDC Nusa Dua-Bali. Tropical Ocean Restaurant and Bar already has 10 restaurants and bars under the brand TROPICAL Restaurant \& Bar, COCO Bistro, OCEAN Restaurant and AROMA Restaurant. Then open a branch in Nusa Dua Bali Collection since December 2006 with the concept of bars and restaurants which stand harmoniously. The bar is located in Bali Collection Block A-14 \# 2, BTDC - Nusa Dua, Bali. From the observation by the author and from interviews with the management of Tropical Ocean Restaurant and Bar obtained the data that guests Tropical Ocean Restaurant and Bar who come to visit are mostly local people (Indonesia) with a percentage of $20 \%$ local and $80 \%$ foreign tourists.

b. Bali Cardamon is a bar located at Jalan Pratama 88 Tanjung Benoa, located right in front of Bali Khama Resort and Spa, a strategic area of Nusa Dua Bali.

c. Tequila Bar is located at Kuta beach road becomes part of the Hotel Grand Istana Rama. From the observation that we do and the results of interviews with management we concluded that most of the guests who come to the tequila bar from Australia, Europe, America and domestic. Tequila Bar open from 15:00 to 01:00 at dawn. One of the most sought drink is Arak Attack Bar and Aracktini.

d. La Scala Restaurant \& Bar is located area of Tanjung Benoa, Nusa Dua Bali. La Scala Bar sells a variety of drinks ranging from Beer, Soft Drink, Fresh Fruit Juice, Coffee, Tea, Wine (House Wine, Wine Hatten) Brandy, Bourbon, Gin, Vodka, Rum, Tequila, Aperitif and liquers. As for cocktails, La Scala Bar provides cocktails and a special non-alcoholic cocktail. La Scala bar also provides a beverage mix with traditional materials, namely Arak Atack.

e. Rosemary's Restaurant and Bar is located at Jalan Sahadewa No.2, Legian Kelod, Kuta, Bali.

f. Stadium Café is located at Jalan Kartika Plaza Complex Kuta Sidewalk, Kuta, Bali. 
g. This Beer Garden bar is located at Jalan Kartika Plaza No. 20, Kuta, Bali. In addition to selling drinks Beer as a main course, this bar also sells a wide variety of mixed drinks both international and traditional.

h. Kedin's Cafe is located at Jl. Poppies Line 1, Kuta, Bali. The bar is managed by local entrepreneurs so that these bars also sell mixed drinks with traditional materials as the mainstay beverages for sale to customers.

i. Kuta Puri Restaurant and Bar is located at Jalan Poppies Lane 1, Kuta, Bali

j. Sandbar is a branch of one of the bars are well known in the Seminyak area called Bistro Batu Kali. Sandbar take a place alongside the Maharani Hotel Kuta. Drinks are served by the Sandbar are highly variable, ranging from nonalcoholic beverages such as juice, coffee, tea, milkshakes, and a mocktail to alcoholic beverages such as beer, cocktails, and wine

\section{Research Result}

From interviews with the manager of the bar and the bartender was obtained answers to the following questions:

1. Type Arak Bali what possible use as an ingredient in mixed drinks to tourists in Bar you?

Type Arak Bali used to make a mixed drink is Arak Bali which has been licensed sales of the Ministry of Health with an alcohol content that already have a standard and safe for consumption by the general public.

2. The mixed drinks any base ingredients using Arak Bali?

Arak Madu

Method: Shaking or Stirring.

Ingredients: 5 cl Arak, $2 \mathrm{cl}$ Lime Juice, 1 cl Honey Garnish: Lime or Lemon

Arak Attack.

Method: Preparing.

Ingredient: $4 \mathrm{cl}$ Arak, $1 \mathrm{cl}$ Grenadine Syrup, Top with Orange Juice Garnish: Orange or Lime

Arak Buck.

Method: Shaking or Stirring.

Ingredient: $5 \mathrm{cl}$ Arak, $1 \mathrm{cl}$ Cointreau, $12 \mathrm{cl}$ Ginger Ale, 1 teaspoon Lemon Juice

Arak Caipirinha.

Method: Stirring.

Ingredient: $5 \mathrm{cl}$ Arak, 8 Lime wedges, 2 teaspoon granulated Sugar

Arak Coke.

Method: Preparing.

Journal of Business on Hospitality and Tourism 
Ingredient: $4 \quad \mathrm{cl}$ Arak, 1 bottle of Coca cola Garnsih: Lime.

Arak Special.

Method: Shaking or Stirring.

Ingredient: $5 \mathrm{cl}$ Arak, $2 \mathrm{cl}$ Lemon Juice, $2 \mathrm{cl}$ Honey, Sprite or $7 \mathrm{Up}$ for top Garnish: Lime or Lemon

3. What is the composition / mixed drink recipes that use basic ingredients Arak Bali?

Use of Arak Bali in most of the mixed drinks are a mixture of main as Arak Bali included into the type of spirit drinks with average usage between 4CL until 5cl. But the recipes that use a mixture of Arak Bali commonly made everything just use a mixture of standard drinks such as for example orange juice, soft drink and lime juice. No one has tried to integrate Arak Bali with beverage ingredients (Spirit and Liquer) others.

4. How is the interest of tourists to the base ingredients mixed drinks using Arak Bali in Bar where you work?

Tourists to drink with traditional materials is very high. But the tourist is still complaining about the lack of variety mixed drink recipes using the main ingredient Arak Bali so impressed that's it and tend to be boring.

\section{Discussion}

From the interview above can be explained that the interest of tourists on a mixed drink with a basis of Arak Bali is actually very high, but most Arak Bali is sold by people still using traditional manufacturing methods and carried out by domestic industry with the equipment used is still simple. So that the alcohol content contained in Arak Bali produced is still undetermined standards and the level of cleanliness is also not guaranteed. Other than that Arak Bali produced by the domestic industry is also still not received official permission from the Ministry of Health so that it can be said is still circulating illegally and therefore can not be used as the main raw material for mixed drinks are sold to tourists at large. Until now, this type of Arak Bali who have obtained permission from the Ministry of Health to be sold widely namely Arak Bali with trademark Dewi Sri which uses fermented rice and fermented coconut water as the main ingredient. Arak Type Dewi Sri has an alcohol content level of some 35 percent.

The types of mixed drink recipes that use a mixture of Arak Bali's main number. Between one bar to the other bars tend to use the same recipe with minimal variation. This is because the type of Arak Bali which can be used also only one type only with a brand that is Arak Bali Dewi Sri. There was also interest from the bartenders to make a recipe creations mixed drinks using basic materials Arak Bali is still considered very less when the demand of tourists to Bali traditional drink is quite high. 


\section{Conclusion}

Based on the presentation and discussion of the results of research that has been described in the previous chapter, can be summarized as follows:

1) Type Arak Bali used as ingredients in the manufacture of mixed drinks are sold at the Bar in Badung only one type that is Arak Bali who holds a license from the Ministry of Health is the brand Arak Bali Dewi Sri.

2) Most Arak Bali produced by the Balinese people are still using the preparation method is simple and yet have clear standards for the content contained therein.

3) There are 6 types of mixed drink recipes that use Arak Bali as a mixture of primary, namely Arak Madu, Atack Arak, Arak Buck, Caipirinha Arak, Arak and Arak Special Coke. Sixth recipe used by many bars located in Badung with variations from one bar to another bar is still very minimal.

4) 4)Use of Arak Bali in mixed drinks are a main ingredient in the composition of the 4CL until 5cl. With this type of Arak Bali used is Arak Dewi Sri who has an alcohol content of 35 percent.

5) The interest of tourists to the mixed drinks that use basic ingredients traditionally very high. But mixed drink recipe creations it is still very lacking.

\section{Sugestion}

Based on the conclusions above it can be delivered suggestion that the government should encourage the domestic industry in the Province of Bali which produce Arak Bali to be able to perform production activities in a more professional and maintain cleanliness. It is also to be made a basic standard on the composition Arak Bali good, so permit circulation of the Department of Health can be obtained by all industry operators households producing Arak Bali. For entrepreneurs bar and bartender who used to use the Arak Bali as an ingredient mixed drinks to improve their creations, especially in making new creations recipes that combine the Arak Bali gredients other drinks that are more widely known by tourists, but by maintaining the hallmark of drinks Arak Bali itself.

The results of this study has limitations that expected their development in subsequent studies. Respondents in this study is confined to the manager and bartender who worked at the Bar in Badung alone. Of course, have different results when performed on a larger area. 


\section{REFERENCE}

Atmodjo, MW.2004.Bar, Minuman dan Pelayanannya.Yogyakarta:ANDI

Amiek, H.2005.Pengetahuan Minuman dan Bar. Bandung:Graha Ilmu.

Bagyono.2007.Pariwisata dan Perhotelan.Bandung.Alfabeta.

Collins, W.2008.The Cocktail Book.William Books,William Collins Sons \& Ltd.Glasgow.Sydney.

Davis, B, dkk.2008. Food And Beverage Management Fourth Edition.Butterworth-heinemann.Elvesier Ltd.

Ensiklopedia Bahasa Indonesia Bebas.2010.Villa, [online], (https://id.m.wikipedia.org/wki/villa, diakses tanggal 17 Juni 2015 ).

Katsigris, C. dan Chris Thomas. 2007. The Bar \& Beverage Book. New Jersey. John Wiley \& Sons, Inc.

Keputusan Menteri Pariwisata dan Ekonomi Kreatif No.23 tahun 2014.

Lumanauw, F.2001.Bar dan Minuman, Petunjuk Praktis Pelaksanaan Beverage Service di Bar Hotel.Indonesia: PT Gramedia Pustaka Indonesia.

Mertayasa, IGA.2012.Food and Beverage Service Operational Job Preparation. Yogyakarta:ANDI.

Ninemier, J.D. and K.Hayes,D.2005.Restaurant operation Management:Princes and Practices.USA:Pelarson Education Inc, Upper Sandle River.new Jersey 0745.

Regan, MH.2003.The Bartender's Best Friend.Jhon Wiley \& Sons, Inc.Hoboken.New Jersey.

Sihite, R.2006.Bar ( Minuman Alkohol). Surabaya:BIC.

Winarti, S.2006.Minuman Kesehatan.Surabaya.PT Naga swadaya. 